\title{
Climate Change and Buildings Energy Efficiency - the Key Role of Residents
}

\author{
Martins MIEZIS ${ }^{1}$, Kristaps ZVAIGZNITIS ${ }^{2}$, Nicholas STANCIOFF $^{1}$, Lars SOEFTESTAD ${ }^{3}$ \\ ${ }^{1} N G O$ "Building and Energy Conservation Bureau", Baznīcas iela 8-22, Rīga, LV-1010, Latvia \\ ${ }^{2}$ Institute of Energy Systems and Environment, Riga Technical University, \\ Azenes iela 12/1, Riga, LV-1048, Latvia \\ ${ }^{3}$ NGO "CBNRM Networking", P.O. Box 1600, NO-4688 Kristiansand, Norway
}

\begin{abstract}
Eastern Europe today is confronted with an unavoidable problem - the multifamily apartment building stock is deteriorating but apartment owners do not have sufficient access to resources be they organizational, financial, technical or legal. In addition, destructive myths have grown about the Soviet era buildings despite their continued resilience or the exGDR experience in the 90s with the same buildings. Further, without resources, decision making in residential apartments is seen as a major obstacle and used as an explanation why renovation has not taken place in Latvia. This is important not only in the context of a potential housing crisis but also because the renovation of the apartment buildings is an effective solution to significantly reduce the energy consumption and greenhouse gas emissions. It has a proven potential to effectively finance the long term renovation of these buildings. This paper summarizes the first findings of a comprehensive and in-depth study of apartment buildings, their owners and the processes relating to renovation, combining social and environmental engineering research methods. It seeks to understand how owners of multi-family buildings in Eastern Europe understand their buildings and then to answer two questions - how to motivate owners to renovate their homes and increase energy efficiency and what business models should be used to implement economically viable and high quality projects.
\end{abstract}

Keywords - Multi-family building; Deep renovation; Decision making; Climate change; Energy efficiency

\section{INTRODUCTION}

Eastern Europe today is confronted with an unavoidable and growing problem - the multifamily apartment building stock is deteriorating but apartment owners do not have sufficient access to resources be they organizational, technical, financial or legal. In addition, destructive myths have grown about the Soviet era buildings despite their continued resilience or the ex-GDR experience in the 90s with the same buildings-renovating 3.6 million apartments in 10 years. Despite this, few buildings have carried out comprehensive renovations: in Europe current renovation rate is about $1 \%[1]$.

In Latvia multifamily apartment buildings account for more than a half of the total heated area of housing stock. In 2009 total heated area of residential buildings was 87 million $\mathrm{m}^{2}$ from which 54.5 million $\mathrm{m}^{2}$ was heated area of multi-family buildings with three and more apartments. $26 \%$ of this area belongs to the buildings built before 1940. Most of these buildings are considered as historical heritage and are under protection. Buildings that were built in 1940 - 1992 account for $63 \%$ of this heated area. The average energy consumption for heating (space heating plus domestic hot water (DHW) circulation losses) of these buildings is $160-180 \mathrm{kWh} / \mathrm{m}^{2}$ a year [2].

* Corresponding author.

E-mail address: martins@ekubirojs.lv

(C2016 Martins Miezis, Kristaps Zvaigznitis, Nicholas Stancioff, Lars Soeftestad. This is an open access article licensed under the

Creative Commons Attribution License (http://creativecommons.org/licenses/by/4.0), in the manner agreed with De Gruyter Open. 
This means enormous energy saving potential as it is possible to achieve on average 40-50\% savings compared with the baseline [3].

Until 2009, multi-family building renovations were done as part of a pilot-projects that were financed by residents themselves of by other countries (for example, Germany) - probably less than 300 [2]. When the co-funding of Structural funds of European Union was available the market started to develop. According to the data of Ministry of Economics in Latvia there has been renovated number of 711 multi-family buildings [4]. 711 buildings are $1.9 \%$ of the total number (38 000) of multi-family buildings. The market stopped in 2014 as soon as the co-funding was closed. There has not been any market development since that time.

The obstacles to renovation have been a subject of research papers for some time now at least since 1997 [5]. Friege and Chappin suggests that research papers that are dealing with energy efficiency in building renovation were missing in depth understanding of decision making by building owners [6]. T'Serclaes also adds that ten years are necessary to change the habits of residents while only three to four years are necessary to introduce the new technologies [7]. Clearly the technologies are not the challenge, especially in renovations: these technologies are not new, they have been used for decades. However, understanding the behavior and decision making process of residents is crucial.

One of the key issues is the private ownership of most of these buildings. In contrast, at reunification in East Germany, municipalities were (and still are) the owners of these buildings and made a coordinated renovation program which lasted 10 years and resulted in over 3.6 million apartments renovated [8].

Further, as Paiho et al. write, owners often do not know each other even if they are living in the same building. Further, different owners can have different income level [9]. Both these facts decrease any sense of solidarity or as was found in an earlier ESEB research: owners go from their car to their apartment without seeing anything in between [10].

Apartments rentals create the landlord/tenant dilemma or split incentives: the interest of the owner is the opposite of the interest of the renter. Research in Denmark demonstrates split incentives: as the tenants are paying the energy bills, the landlord has no interest to invest in energy efficiency measures [11]. However, if the landlord implements energy efficiency measures, he can increase the rent. Williams et al. in research paper mentions that tenants sometimes do not want to ask the landlord to do energy efficiency measures because of the rent increase or the possibility that landlord may evict the tenant and find someone who does not ask for such measures to be implemented [12].

In Latvia there is an apparent lack of interest from the residents and they do not seem to understand that the responsibility for the property belongs with them and not with the government or municipality. Also incomplete regulation can be blamed for creating a barrier. Cimbale mentions that regulation allows selecting representative of the building but it does not say what the duties of this representative are. That creates arguments between representative and maintenance company and this can also create barrier to renovate the building [13].

To involve themselves into as renovation process the owners want tangible benefits after this process. Charlier and Risch mentions that the renovation is more connected to the profits that the owners will get after the renovation than ownership [14]. Baek \& Park further adds that the effects of renovation are sometimes difficult to notice because these effects can be blunted by the increase in energy prices after the renovation, or changes in owner's behavior (increasing room temperature/increase use of hot water) and the long payback of the investment. Energy efficiency is not considered important and it is difficult to show the increase in energy efficiency to possible buyers or tenants [15]. 
The large upfront investments required for any renovation combined with the potential risks, create a decision paralysis. Energy efficiency is not a motive to make such an investment. Paiho et al. suggests that energy efficiency should be coupled with other benefits [9].

Subsidized or distorted energy prices weaken the renovation motivation because the return of the investment is longer and sometimes does not appear profitable due to unrealistically high discount rates. The subsidies distort the market, be they in the form of direct payment supports or tax abatements, and there is no clear information about the real energy prices [7].

Insufficient information has been noted as another obstacle for building renovation. Sometimes it is not possible to get answers to the questions (for example what materials are used for the building during the construction [15], what are the steps if an owner wants to implement energy efficiency measures) or there is misleading information (for example after the renovation the comfort level drops) [7]. This includes professional firms

There are various ways how to do and finance renovation. One of them is on-bill financing. It means that implemented energy renovation measures are financed by energy bill. One of the benefits to this model is simple financing mechanism. But this model will have difficulties if energy is subsidized because the cost of consumed energy may increase [9].

In European Union there is a financial instrument called revolving fund. The fund lends money at low interest rates to projects that are cost-effective. These projects then repay the investment made into the project. The fund can consist of money from government, municipality, donor institutions and sometimes from funds of European Union [16]. This instrument is not applicable in situations where paybacks are longer than seven years: the revolving is glacially slow if payback is 15-25 years as in the case of the buildings under discussion.

Another approach can be seen in Germany. Instead of federal government investments in energy efficiency is funded by the investment bank owned by the Federal and Regional governments of Germany - KfW. KfW supports energy efficiency and renewable energy by providing loans and grants. KfW is a financial institution that is also active in international financial markets [8].

The ESCO model has been very popular and is well known in the world. It implements energy efficiency projects, generates and distributes thermal energy and electricity and performs risk management. An ESCO is interested to implement the most energy efficient solutions for optimal level of investments. One of the way to implement ESCO projects is in the form of Energy Performance Contracting (EPC). The EPC provider or ESCO guarantees the level of energy savings and take over the technical and commercial risks as well as make the investments if the client has not access for funding. [2] Typical length of the EPC is five to ten years in Western Europe where little deferred maintenance needs to be addressed [3]. The EPC model may also used for building deep renovation because the owners may do not have the necessary knowledge to do the building renovation themselves. One example today: in Paris, Posit'if offers financing up to 22 years for building renovations. It includes not only energy efficiency measures but also structural measures like renovation of staircase and other measures to prolong the life of the building as well as to enhance the comfort of residents: installation of new balconies is one possible option given to building owners. The return of the investments of deep renovation project is longer than typical EPC and might be up to 20 years. This model is called an EPC+ model [3], [17].

\section{Methodology}

The research combined two sciences - environmental engineering and social anthropology. It is because the two parts - technical systems of the building and decision making of the residents are interconnected and interact with each other. Qualitative and quantitative methods were used. The qualitative methods used were partially structured interviews and focus group discussions but the quantitative methods used were data gathering and analysis of literature. 
The research was carried out in the five planning regions of Latvia: Riga, Vidzeme, Latgale, Zemgale and Kurzeme. In each region one city was selected. Riga and Daugavpils were selected because these are two largest cities taking into account the number of residents. And Riga and Daugavpils have one of the worst renovation rates in the state. City of Ventspils was selected due to the fact that it is a leader and one of the most successful in multi-family building (MFB) renovation sector. Dobele and Salaspils were selected because these are average size cities (10 000-18 000 residents) and they have slow rate regarding on MFB renovations.

In the selected cities renovated MFB and MFB in ongoing renovation process were chosen. Non-renovated MFB also were selected and served as a control group so that the data are comparable and it is possible to ascertain their credibility. These data were also used to obtain an idea about efficiency of the measures in achieving the energy efficiency. Buildings were selected from different parts of the city, with different number of floors and apartments and other parameters, to ensure as high diversity as possible. A total of 50 buildings ( 25 renovated, and 25 non-renovated), 10 from each city (five renovated, and five non-renovated) were included in the research.

In the engineering part of the study a survey form was developed to gather technical parameters of the building, identify which measures were implemented, collect heat and hot water consumption data and to review terms in the contracts (with construction company, with bank). Basic technical parameters such as series, number of apartments, number of staircases and area of building envelope were compiled. Energy consumption for space heating and hot water consumption data at least for three years before renovation and at least a year after renovation were collected. Total heat consumption was defined as consumption of heat (thermal energy) for space heating, preparation of hot water, and circulation losses of the hot water supply system. In total data for 33 buildings were gathered out of the planned 50 MFB as some residents had not agreed to fill out the survey or refused to provide the data regarding it as confidential.

Data about measures implemented (insulation of walls, attic/roof and basement; replacement of windows, doors etc.) were analysed to find which were implemented the most and the least. To make comparisons between the buildings and define energy savings, climate adjustment and calculation of energy consumption was carried out according to the Cabinet of Ministers Regulation No. 348 "Method for Calculation of Energy Efficiency of the Building". The energy consumption data for space heating were normalized and expressed as energy consumption indicator in $\mathrm{kWh} / \mathrm{m}^{2}$ year.

In social part semi-structured in-depth interviews and focus group discussions were organized. Two methods were used to increase the validity of the research. Guidelines for interviews and discussions were developed based on the questions raised in the research, as well as from the analysis of the literature. The questions were divided in 7 parts: Household characteristics, Home and neighborhood characteristics, The current situation, Renovation process, Street and neighboring houses, Values and climate change, State and local government. The questions are summarized in Table 1.

\section{TABLE 1. INTERVIEW QUESTIONS}

\begin{tabular}{|c|c|}
\hline $\begin{array}{l}\text { Household } \\
\text { Characteristics }\end{array}$ & $\begin{array}{l}\text { 1. How long have you lived here? Why here?: } \\
\text { Is this your apartment? (Ownership, renting, renting from relatives, etc.) What were the } \\
\text { main criteria for choosing this apartment? What do you like in your house? What don't you } \\
\text { like? Have you moved in previous years? What was the reason? } \\
\text { 2. How many people live in this apartment? } \\
\text { 3. Do you plan to move in the near future? Why? }\end{array}$ \\
\hline $\begin{array}{l}\text { Home and } \\
\text { neighbourhood } \\
\text { characteristics }\end{array}$ & $\begin{array}{l}\text { 4. Tell me about your neighbors: } \\
\text { Are you familiar with your neighbors? How long have your neighbors lived here? } \\
\text { 5. How would you evaluate your house - is it friendly, are your neighbors friendly? } \\
\text { 6. Do you have house meetings? }\end{array}$ \\
\hline
\end{tabular}




\begin{tabular}{|c|c|}
\hline & $\begin{array}{l}\text { Who organizes them? Do you attend the meetings? Why? Did you attend the last meeting? } \\
\text { Tell me about the last meeting. } \\
\text { 7. Do you know the house elder well? } \\
\text { Why was this person chosen to be the house elder? How do you assess his performance? If } \\
\text { any other person has been a good home elder, what made them good at it? Who usually } \\
\text { knows the most of what is going on in the house? Which people's opinions do you trust } \\
\text { about what is happening in the house? }\end{array}$ \\
\hline Renovation process & $\begin{array}{l}\text { 8. Tell me about the first time you heard of the idea to insulate the house and restore it? } \\
\text { Who began to talk about it? What was your initial opinion? What persuaded you to carry out } \\
\text { the renovation? Which were the strongest arguments? How did the neighbors react? Did any } \\
\text { neighbors have a very definite opinion about the issue? What was it? } \\
\text { 9. Tell me, what information was available before the start of the project: } \\
\text { Did you know what exactly is going to happen? Was all of the information easy to } \\
\text { understand? Was there some issue/topic you wished was covered better? } \\
\text { 10. Did you read the contract? Who read it from your household? } \\
\text { Was it easy to understand what is going to happen and the commitments you have taken on? } \\
\text { 11. How long was the restoration process? What was it like? } \\
\text { 12. What were the first impressions after the restoration? } \\
\text { 13. What did the neighbors think about the renovation process? } \\
\text { 14. How do you rate your maintenance companies' role in this process? How do you rate the } \\
\text { cooperation with the builders? }\end{array}$ \\
\hline $\begin{array}{l}\text { The current } \\
\text { situation }\end{array}$ & $\begin{array}{l}\text { 15. Tell me about your payments - whether and how they differ from the time before the } \\
\text { renovation. Is it more or less as before the renovation? Are you happy with it? (Heat, } \\
\text { maintenance, electricity). } \\
\text { 16. Do you feel that the apartment and the whole house is warmer? Is it as warm as you } \\
\text { expected? How is it in winter/summer? } \\
\text { 17. What do you think is the biggest benefit of the renovation? Why? } \\
\text { 18. What benefit do you think your neighbors rated the highest? Why? } \\
\text { 19. If you could change something in the house, what would you change? Why? } \\
\text { 20. Have you carried out any apartment renovations on your own? Do you intend to? } \\
\text { 21. Would you have done something to your apartment if the renovation never happened? } \\
\text { (insulation, window change) }\end{array}$ \\
\hline $\begin{array}{l}\text { Street and } \\
\text { neighbouring } \\
\text { houses }\end{array}$ & $\begin{array}{l}\text { 22. Would you say that you live in a good neighborhood? What makes it a good/bad area? } \\
\text { 23. How do you evaluate the houses that were renovated next to yours? } \\
\text { 24. Have you heard something about how did they do? } \\
\text { 25. Why do you think some houses chose the renovation and some didn't? } \\
\text { 26. Do you think that if you would sell your apartment, its value would be greater than } \\
\text { before the renovation? And what about the neighbor houses? }\end{array}$ \\
\hline $\begin{array}{l}\text { Values and climate } \\
\text { change }\end{array}$ & $\begin{array}{l}\text { 27. Do you think that in general it is important to save energy? : } \\
\text { Why? How do you save energy? Is there something that you did before the renovation and } \\
\text { now do not do anymore? What? } \\
\text { When buying new appliances, do you pay attention to how economical/energy efficient they } \\
\text { are? Do you adjust the radiators heat? (Is there such an option?) How many degrees it } \\
\text { usually is? Why? }\end{array}$ \\
\hline $\begin{array}{l}\text { State and local } \\
\text { government }\end{array}$ & $\begin{array}{l}\text { 28. Have you received some support for an apartment or house from the state or local } \\
\text { government? What type? (Housing allowances, the EU funds, low-income status, etc.). } \\
\text { 29. Should state or local government be involved in the restoration of houses? How? Who } \\
\text { should do it? } \\
\text { 30. Do you feel that you can directly influence / change what's going on in the house / area / } \\
\text { city? }\end{array}$ \\
\hline
\end{tabular}

The residents for the interviews were selected based on the placement of their apartment-central part or near outer walls of the building as well as on which floor the resident lives. This was done to make sure that residents from various parts of the building were included because the conditions in the same building may differ depending were the apartment is located in the building. In total 125 semi-structured interviews were performed. Interviews lasted on average 40 minutes ranging from 20 minutes to an hour or longer. During the process of selection of respondents' various demographical parameters were considered, such as age and gender, and other. Demographical 
parameters did no serve as grounds for analysis but they were considered for the purpose to ensure as high diversity of the respondents as possible, as well as to provide for equal opportunities.

In each city two focus group discussions were organized, one for house elders of renovated buildings and another one for house elders of non-renovated buildings. Not all house elders who were interviewed participated in focus group discussions. In total ten focus group discussions were organized and 53 heads of the buildings were present.

During the interviews the age of respondents was between 18 and 83, 57 years on average (median 56), division by gender - 69 women, 56 men were interviewed; and 23 women and 30 men took part in the focus groups. 98 interviews were conducted in Latvian, 27 in Russian, whereas the focus group discussions were conducted in Latvian or bilingually - in both Latvian and Russian.

Interviews were recorded and transcribed. After all, interviews short protocols were written. The transcripts were coded with the interview analysis software Atlas.ti. Using a standard methodology for coding and a systematic approach as designed in Atlas.ti allows for replicability of the study to other areas, cities or countries while ensuring a consistent analysis.

\section{RESUlTS AND DiscuSSION}

Authors have synthesized their findings to explain the results of social and engineering parts in an integrated way. In so doing, it has allowed them to divide the discussion of findings into the four areas of concerns of owners: legal, technical, financial and above all organizational.

\subsection{Social and Organizational Failures}

As mentioned in the introduction, contrary to East Germany, most apartments in Easter Europe were privatized. Generally, for political reasons, rather than economic, the property - apartment and part of the building was devolved to the resident who had no previous experience of ownership and it has been thought that the government or municipality have no right to involve themselves despite articles in the law to the contrary - stating clearly that it is the Government's responsibility to step in when buildings are unsafe.

As a result, one of the obstacles of the building renovation is that Soviet era multi-family building residents consider that only the apartment is their home not the whole building. The functional deficiencies inherent for the whole building at the emotional level are of no concern for the residents. This is better explained by the quote from one of the interviews: "As a matter of fact, the one who lives on the fifth floor understands what a leaking roof is. On the other hand, the one who lives on the ground floor does not care at all" /A respondent from the Zemgale region, during an interview/.

House elders also mention rental apartments as an obstacle which might pose problems during the renovation process because these residents of the building are not entitled to make a decision on renovation. On the other hand, the apartment owners might be both unavailable and unwilling to invest in a building they do not value. If there are several such apartments in the building, then it is a real obstacle to the decision-making. Furthermore, municipal and/or social apartments are also problematic - it is crucial during the period before renovation that the particular municipality supports the idea, and votes in favour for renovation on behalf of these apartments. House elders of the building usually do not understand how to act, if the municipal apartment has a debt - for example, nobody lives in the apartment anymore, it has huge outstanding bills, which impede obtaining a loan from the bank, whereas there is nobody to call to account, if the municipality does not assume the commitments. In the good examples the municipalities tend to pay these debts, thus allowing to commence renovation in the building; however, such examples are too few and too far apart, and mostly found in highly motivated and interested municipalities of small 
towns. In the event of both rental and municipal apartments the residents are of an opinion that liability of the municipality is not clear.

Even if one manages to inform all residents of the building about defects and unsatisfactory condition of the building, it does not mean at all that one has succeeded in convincing about necessity of renovation. Often residents recall being categorically against the renovation. After obtaining a full picture, the negative attitude is mostly replaced by other, more positive. Change of attitude most often manifests from negative to mild, which is characterized by the residents themselves as "it will not get worse/it cannot get worse". The residents opposing renovation are usually convinced over time by the house elder, experts, or other residents: "There was a slight disagreement, but only because not everybody knew the rules" /Respondent from the Latgale region, in an interview/. Change of heart occurs, when the residents understand that there is no loss from renovation, therefore there is no reason not to try. On the other hand, those people who are against continuously and invariably often do not mention specific arguments for their position. Other residents repeatedly mention in the interviews that these opponents cannot resist protesting for the sake of protest: "People almost everybody agreed to everything, only my neighbours downstairs did not agree to absolutely anything. Why so, I don't know, they must be that sort of people." /A respondent from the Latgale region, in an interview/.

The "resident-saboteur" is mentioned repeatedly by respondents in different buildings, who is against the renovation (for example, believes it to be too expensive and does not accept explanation of the expert that there will be saving, while paying the same). These residents tend to be very active and individually approach other residents of the building and convince them to vote against the renovation. "Saboteurs" often succeed in, if not fully convincing, then at least causing enough doubt for people to choose not to actively sign for renovation "to be on the safe side".

Residents often know each other only by sight, less frequently by name or apartment number; closer relationship is comparatively rare. Since residents do not know each other, they do not trust each other (to be more correct - mistrust). Often the only information about other residents of the building is related to debtors (for instance, seeing a list of apartment numbers and amounts of outstanding payments on the wall in the stairway), which only aggravates mistrust and a sceptical attitude towards joint involvement in such a financially burdensome and time-consuming project as renovation. The residents of non-renovated buildings do not know each other and do not trust each other leading to further obstacles to joint decision making.

\subsection{Technical/Engineering Measures and the Mythology of the Soviet Era Buildings}

In all buildings where residents were interviewed or took part in discussions the residents approached told that, in general, they are informed about the possibility and the need to renovate the multi-apartment buildings built in the Soviet era. Information has allegedly been published in both national media and local newspapers, where majority of municipalities inform their residents about the opportunity to renovate the buildings and obtain co-funding of the European Union. Although the residents are informed, not always they agree with this information or trust it. If the information about renovation is obtained from media, the attitude is frequently negative, because media publish mostly scoops about failures: "Some say that it is not effective, it will not work, after a while the mould appear again and so... Have read somewhere online." /A respondent from the Zemgale region, during discussion/.

This subjective feeling about defects of the building and reliance on hearsay is the common thread to reluctance to renovate. Therefore, in the Soviet era multi-apartment buildings only residents exposed to defects of the building on daily basis are the first to think about renovation of the building. Residents of the upper floors were mostly concerned about leaking roofs, noninsulated attics and dangerous elevators. Inhabitants of external or corner apartments are those 
who notice cracks in the walls first. Residents of the ground floor feel the cold and mould spreading from the non-insulated basement, as well as cold coming from the stairway as a result of poor or non-existing entrance door. If the condition of the building does not affect the resident personally, resident will, most probably, be uninterested in improving the situation in some way. Moreover, the residents are often not informed what is happening in other apartments or other parts of the house. Furthermore, if the resident does not encounter the problems on daily basis, the renovation cannot offer or solve anything, because there is nothing to solve.

But despite the information that the buildings must be renovated and the possibilities to do that, interviewees say that they are at loss to understand whether some minor maintenance work on the building, insulation of external walls, deep or comprehensive renovation, or something else is contemplated there. In the market there is a lack of standardization for both procedures and measures necessary to implement from residents point of view. Owners of buildings which were not renovated yet or which had applied for this process were deeply confused, because the surrounding examples of renovation of other buildings showed such different versions of renovation. Even in the buildings where renovation is carried out the residents are not always certain whether what was done on the building can be called renovation. Subsequently, the residents are of an opinion that they are sufficiently informed about the general necessity to renovate the building; however, they confess about confusion what exactly it means.

One is what residents say based on what they know but another aspect is implemented measures in the building according to the actual situation. There can be a possibility that the deep renovation has been implemented but residents do not know this due to lack of information during all project phases: planning, implementation and after the end of project. The summary of implemented energy efficiency measures is summarized in Figure 1.

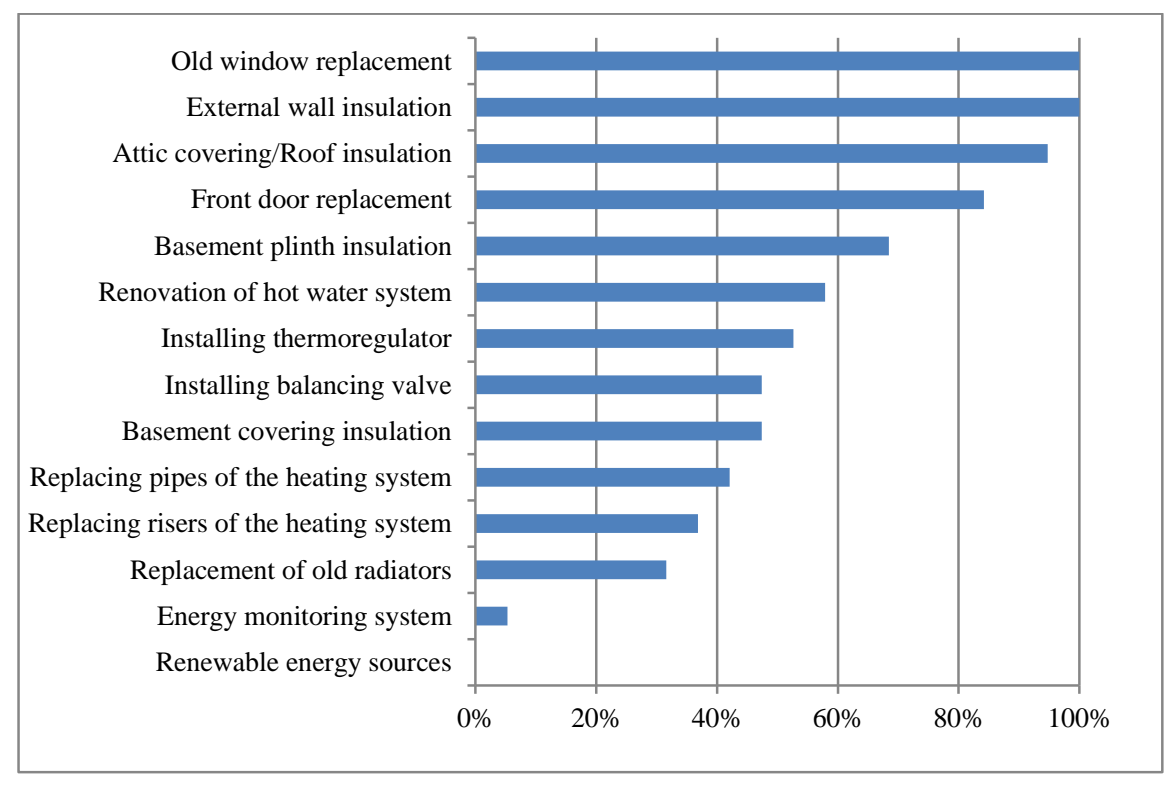

Fig. 1. Implemented energy efficiency measures.

The most common energy efficiency measures are external wall insulation and old window replacement. $100 \%$ of 33 buildings checked, changed their windows which are the private property of their owners, and this proves that multi-family building residents considers only their apartment as their home not the whole building. The next most common measures are attic 
covering/roof insulation ( $95 \%$ of buildings that were included in the study). These are the most common energy efficiency or energy saving measures implemented in buildings. Replacement of old windows has also been done in non-renovated buildings but there are cases where these windows are replaced again to correspond to the new standards. Also some non-renovated houses have insulated end walls decreasing heat losses from the building but during the renovation process all external walls are insulated.

None of the buildings installed renewable energy sources and only $5 \%$ has energy monitoring system installed. More common measures: $32 \%$ of the buildings have replaced old radiators. These measures are the least implemented measures because residents participate in renovation not to save the environment but to decrease their bills and to save their building. Another possibility is that, to install renewable energy sources, a space is needed and in some cases the space around the building is limited or there is none. Energy monitoring system is not very well known measure and so it is not implemented. There is also possibility that residents do not see the usage of that system. The replacement of old radiators could be left out of the project because residents do not see the necessity to do such a step or it is not done to decrease the cost of renovation and implement other more necessary measures instead.

Meanwhile from structural measures that were implemented the most frequently were: roof renovation (84\% of buildings), repair of balconies/loggias (75\% of buildings that has balconies/loggias), and maintenance of ventilation system and repair of the entrance (both $68 \%$ of building). See Figure 2.

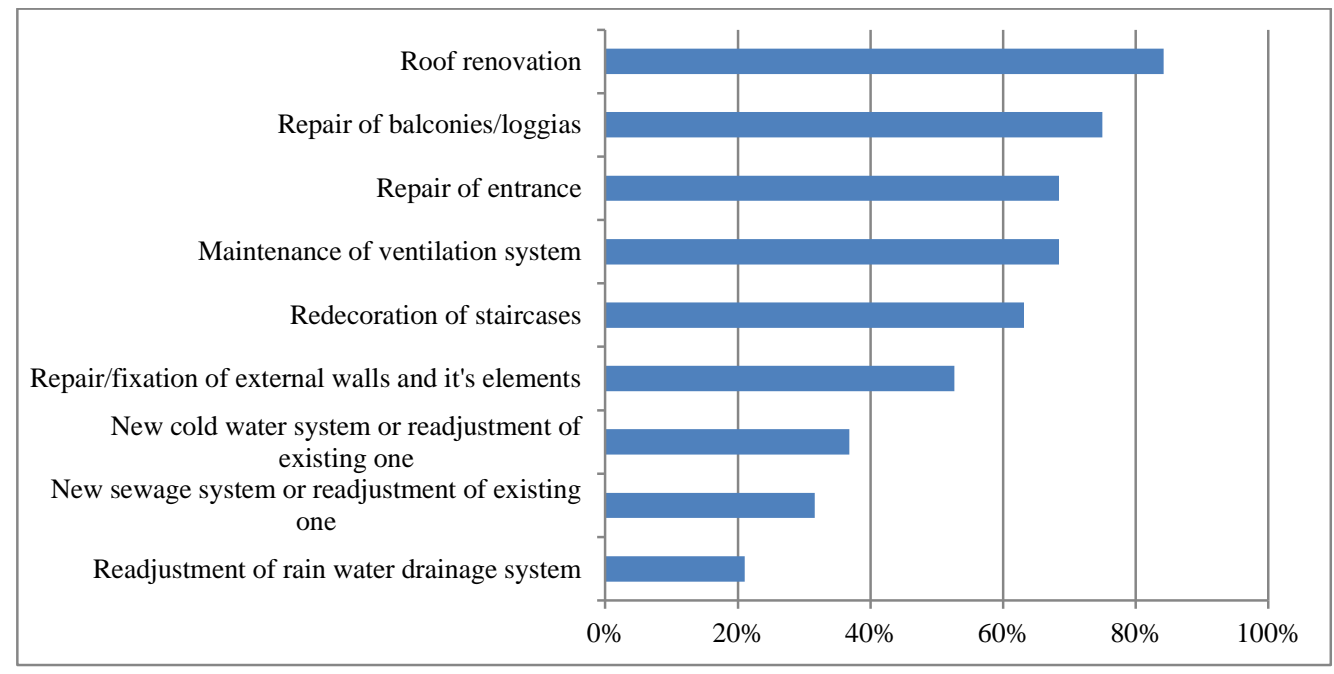

Fig. 2. Implemented structural measures.

It is possible that roof renovation has been done before renovation so it is possible that this measure is not the most common measure implemented during the renovation. The same situation is with repair of balconies/loggias and maintenance of the ventilation system. It is different situation with the repair of the entrance. This measure is more common in the renovated buildings. This means that it is one of the measures implemented during the renovation.

The least implemented measures are readjustment of rain water drainage system $(21 \%$ of buildings) and new sewage system or readjustment of existing one (32\% of buildings). The reason that these measures are not implemented in the renovation process is that the existing system is satisfactory as it is already or to decrease the cost of renovation to include more urgent measures. 
So the investment level necessary for deep renovation is high and residents in most cases choose to exclude important measures.

The technical results have confirmed that there is an uncertainty in every building regarding on measures implemented because listed measures are in range between $21 \%$ up to $100 \%$. All measures listed in both Figures are very important to achieve the best result in long-term regarding on energy savings and sustainability of the building. Therefore, this list should be as standardized package of measures to be implemented in deep renovation project.

\subsection{Financial Obstacles}

These are the obvious ones which all stakeholders agree on: either the building owners do not have funds or cannot or don't want to take loans. So collateral or guarantees are mentioned as a major problem during the planning stage of renovation. Often, municipalities are no longer providing guarantees of credits anymore, and building managers cannot always assume this responsibility. There are a few cases when one of the residents of the building is able to make the first payment - then the pledge is not necessary. Some house elders of non-renovated buildings do not see a way out of this situation, and due to lack of collateral specifically, they are of the opinion that no renovation can occur in their building. Unavailability of guarantees, in general, is mentioned as one of the biggest obstacles and issues during the renovation, because, even if everything else is already done - residents are convinced, the project is drafted - without collateral, it is impossible to receive funding and commence the renovation work.

The interviewees confess that, before the renovation, objections to renovation, were, for the most part, related to financial factors: fear of loans, reluctance to pay more, as well as lack of trust that the neighbours will be able to pay. Most house elders tell that residents are frightened of the mere word "credit" and the fear is rooted in their own negative experience and those around in other crediting situations. Stories from the recession period are still told when level of income rapidly changed for people, and they were not able to repay loans anymore. There is preconception that cooperation with banks regarding credits was complicated and useless. Residents are afraid that cooperation is still the same. Part of older people are worried that, upon borrowing a loan for renovation of the building their apartment will be mortgaged and then foreclosed. Consequently, borrowing and fear associated with it is a material obstacle to renovation.

In small towns or rural regions, where more elderly people live, one of the reasons not to get involved in renovation is conviction that the apartment has no value - either financial or emotional. Arguments of the elderly people are mainly related to future prospects. Those who support renovation say that they want to leave a quality apartment to their children. On the other hand, those residents, who do not support the renovation, mention that they do not wish for the children to inherit their debts. Many other see the emotional value as the only value of the apartment - as a family home. If the children and grandchildren have said that they are not going to live in the small town, the apartment is of no value anymore; therefore, it is not worthwhile to invest either money or efforts in it. In such situations the apartment is a burden, and not a benefit or potential object of investments.

\subsection{Legal Burden}

Drafting of the renovation project and arranging of necessary papers are described as complicated and time-consuming. Usually, some expert is hired at this stage - usually a family member of the house elder or any other resident who has had experience with such kind of work (projects, European funds). It is characterized as a huge advantage, and the interviewees emphasize that without the hired expert they probably would not have drafted the project. House elders of a couple of non-renovated buildings, who took part in the research, acknowledged that they have attempted to draft and submit projects; however, they have not been in sufficiently good 
quality; therefore, they failed to commence the renovation work. The most common criticism towards LIAA (Investment and Development Agency of Latvia) during drafting of the project is related to the fact that they function only as a control mechanism after the project is drafted, while do not help in any other way. Development of the project is complicated, and many house elders are incapable of it; therefore, house elders and residents of those buildings, which do not attract support, face serious difficulties in attracting necessary financing for renovation of the building.

Mistrust of respondents in quality and supervision of construction works is frequently observed. Construction companies are perceived as such which cannot be trusted, because many have personal experience or heard stories where the companies carry out construction works in poor quality, use materials of insufficiently good quality or steal them, and therefore less materials than necessary are used in performance of the works, as well as they may simply disappear without performing the work - sometimes running away with all money. Another obstacle for renovation is the standard three-year warranty of the construction works. Residents consider it to be disproportionately short, especially in comparison with the period of loan (for example, the 3-year warranty and the loan for 15 years). Consequently, the residents are concerned about quality, supervision of the construction works and are dissatisfied with the short duration of the warranty.

\section{Conclusion}

The overall conclusion is that residents are right not to trust in the process and the results of renovations. Each of our conclusions supports in some way the need to build confidence in the process, confidence in the social fabric, confidence in the technical recommendations, confidence in the financial outcomes and confidence in the legal framework to ensure a level playing field.

Organizational and Legal confidence:

- Owners need to be organized in housing associations and need to have access to advice on how to organize themselves. This will help both the social and organizational problems as well as alleviate the legal burden.

- Furthermore, arguments about benefits for the building as a community are much less effective before the renovation though as was seen in earlier research " Residents' understanding and perception of the impact of renovation of multifamily dwellings", once the renovation has been made in a manner satisfactory to owners, the community process continues to grow and as a community, further decision are made [3]. Therefore, to accomplish renovation of the building it is important to inform the residents in a form comprehensible to them about its defects and explain to them how each of the defects and elimination thereof may influence quality of life of the individual.

- Project development is understood to be a complicated process, during which residents need support. The management company or any renovation service provider sometimes takes part in development of the project, whereas other times voluntary or hired people are engaged who have experience and relevant skills. Furthermore, the house elder is frequently forced to learn and implement important aspects of project development on his own. This not only delays the process but also becomes a real obstacle for launching renovation and endangers to good conduct of the work. Therefore, it is necessary to develop clear forms of support during the stage of project development.

Technical/Engineering Confidence:

- In the findings it was found that the most commonplace confusion is about the notion of renovation - what does it include? In most cases residents include the measures for which there is a lot of information. But in some cases these measures are not enough to achieve the goals that residents want. Therefore, it is necessary to develop clear set of measures 
which can be called a renovation and the criteria, demonstrating achievement of the measures. Residents could then understand with security what they are "buying".

- It was also confirmed that that residents do not have the necessary organizational, financial, technical and legal knowledge to draft and implement good quality projects, combining this with aforementioned need for clear set of measures, authors suggest offering comprehensive solutions for buildings: standardized packages of measures.

- One possible approach is for housing associations to work within an EPC+ framework. The EPC+ ensures that the warranty for implemented measures matches the payback period of the investments and that the service provider guarantees the quality of works by outlining a clear and legal agreement which will describe the steps to prepare, implement the project and measure the results.

- Achieved energy saving for space heating depends on implemented measures, their quality and habits of residents. In 10 cases from 18 less than $50 \%$.

- In all cases, Measurement and Verification should be standardized and obligatory, ideally in the form of an energy certificate as with televisions or refrigerators today.

Financial Confidence:

- In decision-making about renovation, residents consider first short term personal gains versus the long term financial risks. If the resident and his family do not feel discomfort at their home, then motivation to support the renovation is insignificant or non-existent. On the other hand, residents who encounter defects of the building on daily basis are able to identify benefits of renovation, and support the renovation more eagerly.

- Initially, a renovation project is often perceived confusing and risky, because the information received about it is varies depending on the source of information. Renovated buildings are examples of good practice, where the house elder provided the residents with information on a regular basis and shared the processes required honestly and in great detail. This is important both before renovation because of the size of financial commitments, potential risks, whereas at later stages it is important for the residents to be informed about the course of construction and other developments as these impact their everyday life.

Legal confidence:

- A registry of construction companies is needed where owners and board of the company are shown as well as implemented projects by this company. Through the registry, residents can be confirming that the construction company will implement project in good quality.

During allocation of the EU structural funds and after them there has to be an institution that could help residents and give information what is renovation, and what measures it includes. Also this institution could help residents who wish to do renovation to their house.

\section{ACKNOWLEDGEMENT}

The paper was prepared in the framework of the project "Renovation Impact on Climate Change and Energy Efficiency Habits of Residents" lead by the Building and Energy Conservation Bureau (ESEB). The project was implemented using co-funding of the financial instrument of the European Economic Area managed by local authority the State Regional Development Agency. The authors wish to thank for their contributions first and foremost: Mara Laizane and Ilze Vardanjana, but also all the residents which provide us with their time and support for the research as well as our project partners Institute of Energy Systems and Environment of Riga Technical University (Latvia) and CBNRM Networking (Norway). For more information about the project please visit www.ekubirojs.lv where the findings are shared and further developed. 


\section{REFERENCES}

[1] The Renovate Europe Campaign. Current Situation. Infographics [Online]. [Accessed: 02.04.2016]. Available: http://renovate-europe.eu/wp-content/uploads/2015/10/current-situation.jpg

[2] Zvaigznītis K. Energy Efficiency Based Financial Instruments for Large Scale Deep Renovation of Multi-family Dwellings. Master thesis. Riga: Institute of Energy Systems and Environment, 2014.

[3] Rochas C., Zvaigznītis K., Kamenders A., Žogla G. Energy performance contracting for multi-family buildings in Latvia. First steps. Presented at 9th International Conference on Environmental Engineering, Vilnius, Lithuania, 2014. doi:10.3846/enviro.2014.279

[4] Ministry of Economics of Latvia. Statistics of Renovated buildings [Online]. [Accessed: 20.12.2015]. Available: https://www.em.gov.lv/lv/es fondi/dzivo siltak/renoveto eku statistika/

[5] Martinot E. Investments to Improve the Energy Efficiency of Existing Residential Buildings in Countries of the Former Soviet Union. Washington, DC: World Bank, 1997.

[6] Friege J., Chappin E. Modeling decisions on energy-efficiency renovations: A review. Renewable and Sustainable Energy Reviews 2014:196-208. doi:10.1016/j.rser.2014.07.091

[7] International Energy Agency. Financing Energy Efficient Homes: Existing policy responses to financial barriers. IEA $\begin{array}{llll}\text { information } & \text { paper } & \text { [Online]. 24.08.2015]. }\end{array}$ https://www.iea.org/publications/freepublications/publication/FinancialBarrierBuilding.pdf

[8] Schröder M., Ekins P., Power A., Zulauf M., Lowe R. The KfW Experience in the Reduction of Energy Use in and CO2 Emissions From Buildings: Operation, Impacts and Lessons For the UK. London: UCL Energy Institute, 2011. http://sticerd.1se.ac.uk/dps/case/cp/KfWFullReport.pdf

[9] Paiho S., Abdurafikov R., Hoang H., Kuusisto J. An analysis of different business models for energy efficient renovation of residential districts in Russian cold regions. Sustainable Cities and Society 2015:31-42. doi:10.1016/j.scs.2014.07.008

[10] Building and Energy Conservation Bureau. Social Study: Residents' understanding and perception of the impact of renovation of multifamily dwellings. Riga: Building and Energy Conservation Bureau, 2014.

[11] Ástmarsson B., Jensen P.A., Maslesa E. Sustainable renovation of residential buildings and the landlord/tenant dilemma. Energy Policy 2013:355-362. doi:10.1016/j.enpol.2013.08.046

[12] Williams BE. Overcoming Barriers to Energy Efficiency for Rental Housing. Master thesis. Massachusetts: Department of Urban Studies and Planning, 2004.

[13] Cimbale A. The Impact of Authorized Representatives on Energy Efficiency in Multifamily Apartment Houses and Prolongation of the Lifetime of the Buildings. Presented at REHVA Annual Conference 2015 "Advanced HVAC and Natural Gas Technologies", Riga, Latvia, 2015. doi:10.7250/rehvaconf.2015.036

[14] Charlier D., Risch A. Evaluation of the impact of environmental public policy measures on energy consumption and greenhouse gas emissions in the French residential sector. Energy Policy 2012:170-184. doi:10.1016/j.enpol.2012.03.048

[15] Baek C., Park S. Policy measures to overcome barriers to energy renovation of existing buildings. Renewable and Sustainable Energy Reviews 2012:3939-3947. doi:10.1016/j.rser.2012.03.046

[16] Ministry of Economics. Informative report about building renovation financing solutions. [Online] [Accessed: 20.12.2015]. Available: https://www.em.gov.lv/files/majokli/IZ_6.doc

[17] Cheyrou L., Forni D et.al. New and existing business models for energy services. Executive Summary: 2011.

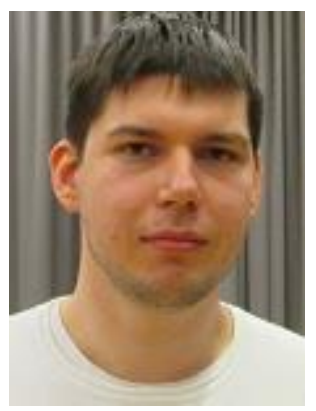

Martins Miezis received B.Sc. degree in Environmental Science from Riga Technical University, Institute of Energy Systems and Environment in 2013. He received the M.Sc. degree in Environmental Science from Riga Technical University, Institute of Energy Systems and Environment in 2015.

Currently Martins Miezis works as Research Analyst in NGO "Building and Energy Conservation Bureau" in Latvia.

E-mail: martins@ekubirojs.lv 

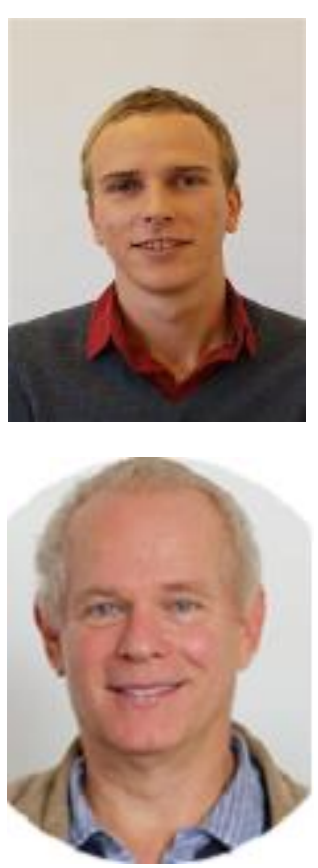

Kristaps Zvaigznitis received Master's degree in Environmental Science graduating Riga Technical University in 2014 and since that is a PhD student. He has in-depth knowledge and practical experience in the field of energy efficiency and renewable energy in building sector covering technical, financial, legal and social aspects as well as in-depth expertise of energy performance contracting.

Kristaps holds the position of the Co-director at NGO "Building and Energy Conservation Bureau" (ESEB) since summer 2014. He started to work at ESEB as junior researcher when the NGO was founded.

Address: Juglas Street 35-28, Riga, Latvia, LV-1064.

E-mail: Kristaps.Zvaigznitis@rtu.lv

Nicholas Stancioff received a Masters in business administration from the Darden School, University of Virginia, 1986 and a Batchelors in Arts - mathematics and literature (cum laude) from the American University, Washington, DC.

Nicholas Stancioff has been an innovator in the fields of language, computing, organizational systems and finance. He has worked as a trader, a banker and an investor with strong start-up experience. He currently is the managing director of F3, Egmond, Netherlands and its first fund: LABEEF in Riga, Latvia. June 2012, he created the Housing and Energy Conservation Bureau, advocating for residents of multi-family panel buildings. From 2005 to 2012, with partners, he took public the first Bulgarian REIT. From 19982008, worked as a turn-around specialist and sovereign debt advisor. From 1993-1998, as a banker with EBRD, he closed transactions in the nascent private sector while participating in institution building efforts. He also gained in-depth expertise in structuring and managing public and private sector project finance in emerging market countries. From 1988-1992, as a physicals and futures commodities trader, he pioneered options pricing engines before being tasked with M\&A responsibilities in the US and the Caribbean while designing the first trade to balance sheet commodities portfolio system (ISIS). From 1981-1986, he taught languages, started a language school, designing its teaching methodology, and created the first voice recognition based language training system (CALT). A native speaker of English and French, he is proficient in Bulgarian, Portuguese and Spanish.

Address: Baznicas Street, Riga, Latvia, LV-1010.

E-mail: nicholas@stancioff.com

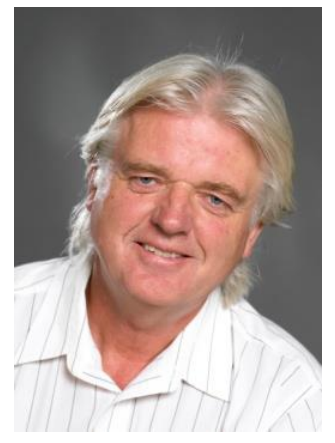

Lars Soeftestad received the BA in social anthropology from Univ. of Bergen (1975), the Cand. Mag. in biology and sociology from Univ. of Oslo (1978), and the Ph.D. (abb) in anthropology from Univ. of Zurich (1993).

He is Founder and CEO of Supras Ltd. (Norway and Bulgaria). Previously he worked as Anthropologist, Norad, Asst. Professor in Anthropology, Univ. of Zurich and Anthropologist, World Bank. His research interests focus on democratization, inclusion, participation and transparency.

Memberships: American Anthropological Association, Consulting Mgmt. Platform (Gerson Lehrman Group), Institute for Applied Anthropology, Univ. of Dhaka, Norwegian Ass. for Development Research, Norwegian Evaluation Society, South Norway European Office, UN Convention to Combat Desertification (UNCCD), Water and Culture Institute (USA).

Address: PO Box 1600, NO-4632 Kristiansand, Norway. Mobile: +47 90823006.

Email: mail@supras.biz 